\title{
Simultaneous Estimation of Satranidazole and Ofloxacin in Tablet Dosage Form by High Performance Liquid Chromatography
}

\author{
R. SHINDE SACHIN*, I. BHOIR SUVARNA, S. PAWAR NAMDEV, \\ B.YADAV SUMAN and M. BHAGWAT ASHOK
}

\author{
Shri C.B. Patel Research Centre, \\ $3^{\text {rd }}$ Floor, Bhaidas Hall Bldg, JVPD Scheme, \\ Vile-Parle (west), Mumbai - 400056. \\ shinde.sachin.r@gmail.com
}

Received 30 June 2009; Accepted 20 August 2009

\begin{abstract}
A Simple, fast and precise reversed phase high performance liquid chromatographic method is developed for the simultaneous determination of satranidazole and ofloxacin. Chromatographic separation of these drugs were performed on Kromasil $\mathrm{C}_{18}$ column $(250 \times 4.6 \mathrm{~mm}, 5 \mu)$ as stationary phase with a mobile phase comprising of $20 \mathrm{mM}$ potassium dihydrogen phosphate: acetonitrile in the ratio of $60: 40(\mathrm{v} / \mathrm{v})$ containing $0.1 \%$ glacial acetic acid at a flow rate of $1 \mathrm{~mL} / \mathrm{min}$ and $\mathrm{UV}$ detection at $318 \mathrm{~nm}$. The linearity of satranidazole and ofloxacin were in the range of 1.5 to $3.6 \mu \mathrm{g} / \mathrm{mL}$ and 1.0 to 2.4 $\mu \mathrm{g} / \mathrm{mL}$ respectively. The recovery was calculated by standard addition method. The average recovery was found to be $100.63 \%$ and $100.02 \%$ for satranidazole and ofloxacin respectively. The proposed method was found to be accurate, precise and rapid for simultaneous determination of satranidazole and ofloxacin.
\end{abstract}

Keywords: Satranidazole, Ofloxacin, RP-HPLC, Tablet.

\section{Introduction}

Satranidazole (SAT), is a novel nitroimidazole derivative. Chemically, it is 1-methylsulfonyl-3-(1methyl-5-nitro-2-imidazolyl)-2-imidazolidinone ${ }^{1}$. It is used as antiprotozoal and anitibacterial agent in the treatment of amoebiasis. Ofloxacin (OFL) is a fluoroquinolone derivative. Chemically, it is ( \pm )-9-fluoro-2, 3-dihydro-3-methyl-10-(4-methyl-1-piperazinyl)-7-oxo-7H-pyrido-[1,2,3-de]-1,4 benzoxazine-6- carboxylic acid ${ }^{2}$. It is mainly used as antibacterial for the treatment of urinary tract infection and sexually transmitted diseases. Ofloxacin is official in $\mathrm{USP}^{3}$ and $\mathrm{BP}^{4}$ whereas satranidazole is not official in any Pharmacopeia. Literature survey revealed that a number of methods have been reported for estimation of ofloxacin individually or in combination with other drugs ${ }^{5-10}$ and satranidazole is estimated individually ${ }^{11-13}$. However there is only one analytical method reported for this combination of drugs by using spectrophotometer ${ }^{14}$.

For best of our knowledge, no method has been reported for simultaneous determination of satranidazole and ofloxacin by HPLC. Hence, an attempt has been made to develop new RP-HPLC method for its simultaneous estimation in pharmaceutical dosage form with good accuracy, precision and simplicity. 


\section{Experimental}

The formulations, satrogyl-o tablet (containing $300 \mathrm{mg}$ of satranidazole and $200 \mathrm{mg}$ ofloxacin; manufactured by Alkem Laboratories Limited, Baddi), were procured from pharmacies. Satranidazole working standard was obtained as a gift sample from Alkem laboratories, Ofloxacin from Zhejianh Kangyo Pharm. Co. Ltd. Acetonitrile and methanol were of HPLC grade purchased from E-Merck (India) Ltd. Glacial acetic acid used were of analytical grade purchased from Spectrochem Pvt. Ltd. Potassium dihydrogen ortho phosphate was of AR grade purchased from Qualigens Ltd.

\section{Instrument}

The analysis was carried on the integrated HPLC system (Agilent 1100 series, Germany) consisted of G1311A Quaternary pump with G1379A Degasser, G1329A Autosampler (1-100 $\mu \mathrm{L})$ with G1330B Autosampler Thermostat, G1316A Column Compartment with temperature controller and G1314A VWD UV detector. Chromatograms were processed and the results were analyzed by using Chemstation software (Rev.10.01).

\section{Optimized chromatographic condition}

$\begin{array}{lcl}\text { Analytical Column } & : & \text { Kromasil 100-5C18, }(250 \times 4.6 \mathrm{~mm}, 5 \mu \mathrm{m}) . \\ \text { Mobile Phase } & : & \begin{array}{l}20 \mathrm{mM} \text { Potassium dihydrogen phosphate: } \\ \text { Acetonitrile }(60: 40) \text { containing 0.1\% glacial }\end{array} \\ & & \begin{array}{l}\text { acetic acid. } \\ \text { UV Detection }\end{array} \\ \text { Flow Rate } & : & 318 \mathrm{~nm} \\ \text { Injection Volume } & : & 5 \mu \mathrm{L} \\ \text { Temperature } & : & \text { Ambient } \\ \text { Run Time } & : & 8.0 \mathrm{~min} . \\ \text { Retention Time } & : & \text { Ofloxacin } ~ 2.29 \\ & & \text { Satranidazole } ~ 4.80\end{array}$

Satranidazole and ofloxacin standard stock solution-I and II $(1 \mathrm{mg} / \mathrm{mL})$ were prepared by dissolving $10 \mathrm{mg}$ of the drug in $10 \mathrm{~mL}$ methanol and further dilutions were prepared in mobile phase to obtain calibration standards in the concentration range of $1.5-3.6 \mu \mathrm{g} / \mathrm{mL}$ and $1.0-2.4 \mu \mathrm{g} / \mathrm{mL}$ respectively.

\section{Linearity}

Eight different concentrations from 1.5-3.6 $\mu \mathrm{g} / \mathrm{mL}$ for satranidazole and $1.0-2.4 \mu \mathrm{g} / \mathrm{mL}$ for ofloxacin were prepared for linearity studies. The responses were measured as peak areas and plotted against concentrations. Linear regression least square fit data obtained from the above calibration curve. The respective slopes (m), intercept (b) and correlation co-efficient (r) are also obtained. A typical HPLC chromatogram is shown in Figure 1.

\section{Sample preparation}

Twenty tablets were weighed and average weight was calculated. These tablets were powdered. Weight equivalent to the one tablet was taken in a $100 \mathrm{~mL}$ volumetric flask; dissolved in minimum amount of mobile phase and diluted up to the mark with the same. The solution was then filtered through a Whatmann filter paper no. 41 and filtrate was collected in the flask. $0.1 \mathrm{~mL}$ of the filtrate was diluted to $100 \mathrm{~mL}$ with mobile phase to get $3 \mu \mathrm{g} / \mathrm{mL}$ of satranidazole and $2 \mu \mathrm{g} / \mathrm{mL}$ of ofloxacin. 


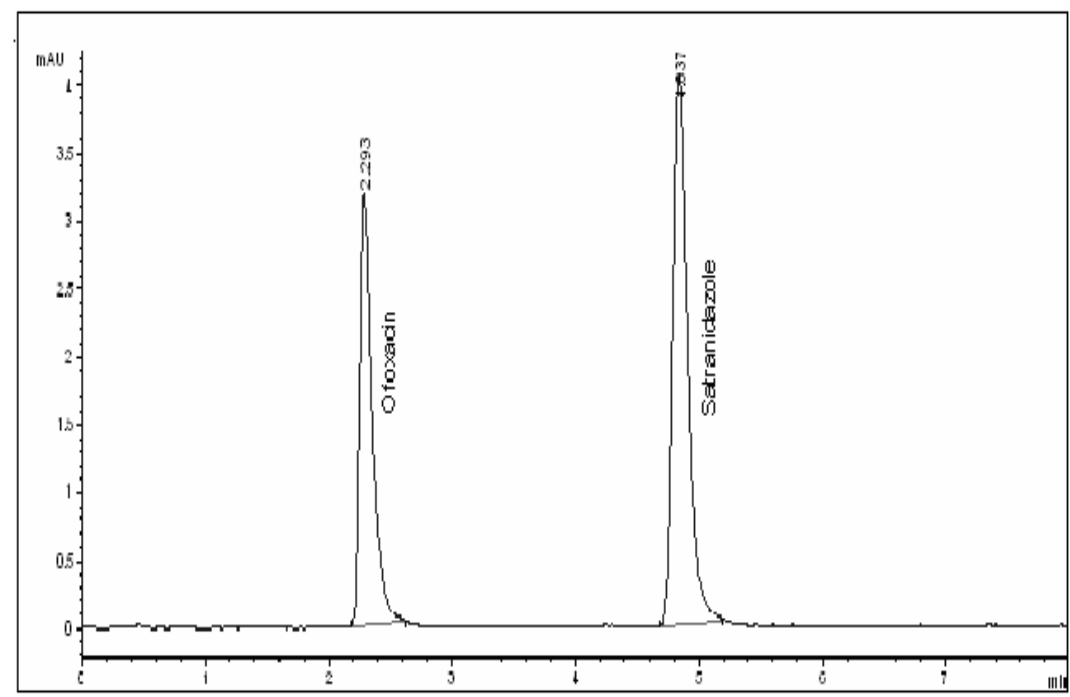

Figure 1. Typical HPLC chromatogram showing ofloxacin $(2 \mu \mathrm{g} / \mathrm{mL})$ and satranidazole $(3 \mu \mathrm{g} / \mathrm{mL})$. Assay

From the above sample solution $5 \mu \mathrm{L}$ was injected along with the same concentration of the standard solution under the optimized chromatographic conditions. The peak area values of satranidazole and ofloxacin were calculated. The peak area values of SAT and OFL present in that solution was then estimated using calibration curve method. Results of the assay are tabulated in Table 1 .

Table 1. Results of assay experiment.

\begin{tabular}{lccll}
\hline Drug & Labeled claim, mg & Amount found $(\mathrm{n}=6)$ & \%RSD & \%Assay \\
\hline Satranidazole & 300 & 300.05 & 1.45 & 100.02 \\
Ofloxacin & 200 & 203.61 & 2.07 & 101.80 \\
\hline
\end{tabular}

\section{Recovery}

Recovery experiments were carried out to check for the presence of positive or negative interferences from excipients present in the formulation and to study the accuracy and precision of the method. Recovery experiment was performed by the standard addition method. ${ }^{[15]}$ The recovery of the standard was studied at the three different levels viz. $80 \%$, $100 \%$ and $120 \%$ of the estimated amount of drug. Each set of recovery of added standard was calculated. The results of recovery experiment are tabulated in Table 2.

Table 2. Recovery studies of satranidazole and ofloxacin

\begin{tabular}{llllll}
\hline Drug & $\begin{array}{c}\text { Original mount, } \\
\mathrm{mg}\end{array}$ & $\begin{array}{c}\text { Added amount, } \\
\mathrm{mg}\end{array}$ & $\begin{array}{l}\text { Total amount } \\
\text { found, } \mathrm{mg}\end{array}$ & \%Recovery & \%RSD \\
\hline \multirow{3}{*}{ SAT } & 300 & 240 & 539.85 & 99.97 & 0.877 \\
& 300 & 300 & 611.03 & 101.84 & 1.197 \\
& 300 & 360 & 660.57 & 100.09 & 1.222 \\
\hline \multirow{3}{*}{ OFL } & 200 & 160 & 356.93 & 99.15 & 2.063 \\
& 200 & 200 & 404.36 & 101.09 & 2.764 \\
& 200 & 240 & 439.24 & 99.83 & 3.685 \\
\hline
\end{tabular}

( $n=$ each value is average of three determination) 


\section{The limit of quantitation (LOQ) and limit of detection (LOD)}

The limit of detection (LOD) and quantification (LOQ) were evaluated from calibration curves plotted in concentration ranges of $0.150-0.360 \mu \mathrm{g} / \mathrm{mL}$ for satranidazole and 0.100 $0.240 \mu \mathrm{g} / \mathrm{mL}$ for ofloxacin, with formula $\mathrm{LOD}=3.3 \mathrm{syx} / \mathrm{S}$ and $\mathrm{LOQ}=10 \mathrm{syx} / \mathrm{S}$ (where syx = residual error and $\mathrm{S}=$ slope of the calibration curve). The LOD and LOQ for each drug were thus obtained. Thereafter, the standard drug solutions at each value of LOD and LOQ concentration were injected six times and \% RSD of area of the replicate injections were calculated.

\section{Ruggedness}

Ruggedness tests were performed on HPLC assay of satranidazole and ofloxacin of pharmaceutical tablet and peak area response of standard solution. The effects of different chromatographic columns by different analysts on different days were evaluated on $\%$ assay of pharmaceutical tablet and peak area response of standard solutions. The \% RSD not more than 3 indicting good ruggedness of the developed HPLC method.

\section{Robustness}

Robustness of the method was ascertained by evaluating the effect of deliberate change $\mathrm{pH}$ of the mobile phase by adding different volumes of glacial acetic acid, proportion of organic solvent in mobile phase and flow rate. The $\mathrm{pH}$ of mobile phase was varied within a range of \pm 0.2 unit of the optimize $\mathrm{pH}$ (4.0) by adding different volumes of glacial acetic acid. While proportion of organic solvent (acetonitrile) was varied in the range of $\pm 2 \%$. The mobile phase were employed, keeping the other chromatographic conditions constant, to evaluate the influence of $\mathrm{pH}$ and organic solvent on resolution between two drugs. Keeping other chromatographic conditions optimized different flow rates $\pm 0.1 \mathrm{~mL} / \mathrm{min}$ were employed to check influence of flow rate on the proposed method (Table 3).

Table 3. Robustness study for satranidazole and ofloxacin.

\begin{tabular}{|c|c|c|c|c|c|c|c|c|c|}
\hline \multirow[b]{2}{*}{$\begin{array}{l}\text { Studied } \\
\text { Parameter }\end{array}$} & \multicolumn{3}{|c|}{$\begin{array}{c}\text { Volume of acetic acid } \\
\text { added in MP }\end{array}$} & \multicolumn{3}{|c|}{$\begin{array}{c}\text { Change in ACN } \\
\text { Composition }\end{array}$} & \multicolumn{3}{|c|}{$\begin{array}{c}\text { Change in } \\
\text { Flow rate, } \mathrm{mL} / \mathrm{min} \\
\end{array}$} \\
\hline & $\begin{array}{l}0.5 \% \\
\mathrm{pH}: \\
4.20\end{array}$ & $\begin{array}{c}\text { (Ideal) } \\
1.0 \% \\
\text { pH: } 4.00\end{array}$ & $\begin{array}{c}1.5 \% \\
\text { pH: } 3.80\end{array}$ & $62: 38$ & $\begin{array}{l}\text { (Ideal) } \\
60: 40\end{array}$ & $58: 42$ & 0.9 & $\begin{array}{l}\text { (Ideal) } \\
1.0\end{array}$ & 1.1 \\
\hline $\begin{array}{l}\% \text { Assay } \\
\text { Satranidazole }\end{array}$ & 100.56 & 100.03 & 101.36 & 99.20 & 100.64 & 100.18 & 100.18 & 100.51 & 99.45 \\
\hline $\begin{array}{l}\% \text { Assay } \\
\text { Ofloxacin }\end{array}$ & 101.20 & 100.52 & 101.68 & 100.26 & 100.48 & 101.50 & 100.85 & 100.25 & 101.28 \\
\hline
\end{tabular}

\section{Results and Discussion}

The reverse phase high performance liquid chromatography method was optimized with a view to developed a simple assay method. Pure drugs chromatogram was run in different mobile phase containing methanol, acetonitrile, water and different buffers in different ratios. Different columns such as $\mathrm{C}_{8}, \mathrm{C}_{18}$ with different dimension were used. Finally $\mathrm{C}_{18}$ column and mobile phase containing 60:40 buffer and acetonitrile was selected which gave tailing of both the drug. Hence glacial acetic acid was used to reduce the tailing. System suitability parameter was tested which indicate that the proposed LC method permitted adequate resolution of the mixture components within the reasonable run-time. In addition high column efficiency was indicated from the large number of theoretical plates $(>3000)$. 
The degree of asymmetry was also evaluated using the tailing factor, which did not exceed the critical value (1.5) indicating acceptable degree of peak asymmetry. The optimum wavelength for detection was found to be $318 \mathrm{~nm}$, wherein both the analytes were detected. The linearity of the calibration curves indicates the suitability of the method over a wide range of concentration. Regression analysis of the calibration data for satranidazole and ofloxacin showed that the dependant variable (peak area) and the independent variable (concentration) were represented by the equations: $\mathrm{y}=\mathrm{m} \mathrm{x}+\mathrm{b}$ was found to $\mathrm{y}=9.5827 \mathrm{x}+1.7619$ and $\mathrm{y}=$ $10.9772 \mathrm{x}+0.0533$ for satranidazole and ofloxacin respectively. The correlation of coefficient $\left(\mathrm{r}^{2}\right)$ obtained was found to be 0.9991 and 0.9995 for satranidazole and ofloxacin respectively. The sensitivity of the method was found to be good from LOD and LOQ of the analytes. The average \% recovery for satranidazole and ofloxacin shows that method is free from interference like excipients present in the formulation. The standard deviation of $\%$ assay for sample was calculated for each parameter and relative standard deviation was found to be less than $2 \%$. The low R.S.D. value indicated robustness of the method.

\section{Conclusion}

The LC method proposed for the determination of satranidazole and ofloxacin in a tablet formulation was successfully developed and validated for its intended purpose. This analytical method was found to be simple, linear, precise, and rugged for the determination of satranidazole and ofloxacin in tablet dosage form. This analytical method is adequate and useful for the estimation of satranidazole and ofloxacin in tablet for quality control laboratories, where low cost and fast analysis are essential.

\section{Acknowledgements}

Authors are thanks to Mr. Sunder Natarajan, Alkem Laboratories Limited, Mumbai for providing the working standard of satranidazole.

\section{References}

1. http://sci-toys.com/scichem/jqp016/41841.html.

2. Sweetman S C, In Martindale, The Complete Drug Reference. London: Pharmaceutical Press, London., 2005, 34 ${ }^{\text {th }}$ Ed., 239.

3. United State Pharmacopoeia, United State Pharmacopoeial Convention, Inc. 2003; $26^{\text {th }}$ Ed., 1334.

4. British Pharmacopoeia. H M, Stationary Press, London, 2007, II, 1163.

5. Immanuel C and Kumar A K H, J Chromatogr B Biomed Sci Appl., 2001, 760, 91-95.

6. Panzade P D and Mahadik K R, Indian Drugs, 2001, 38, 368-370.

7. Nagori B P, Shrivastava B, Sharma V and Rajput A S, Indian Drugs, 2006, 43, 676-678.

8. Halkar U P and Ankalkope P B, Indian Drugs, 2000, 37, 585-588.

9. Kamble N S and Venkatachalam A, Indian Drugs, 2005, 42, 723-725.

10. Kalta R R and Sharma R, Indian J Pharm Sci., 2008, 70(4), 491- 494.

11. Patel M B, Patel K M, Patel G S, Suhagia B N and Prajapati A M, J Liq Chromatogr Rel Technol., 2007, 30, 2459-2471.

12. Wankhede S B, Prakash A and Chitlange S S, Res J Pharmacy Tech., 2008, 1(4), 441- 443.

13. Natarajan S and Raman B, Asian J Chem., 2008, 20(3), 1833- 1840.

14. Wankhede S B and Prakash A, Asian J Res Chem., 2008; 1(1), 9-11.

15. ICH Q2A, Text on validation of analytical procedures, International Conference on Harmonization tripartite guidelines, adapted 27 Oct 1994B. 


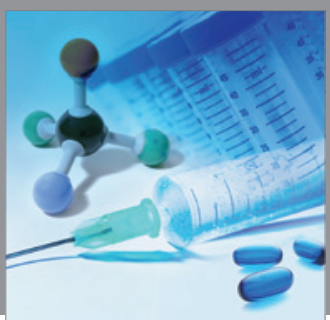

International Journal of

Medicinal Chemistry

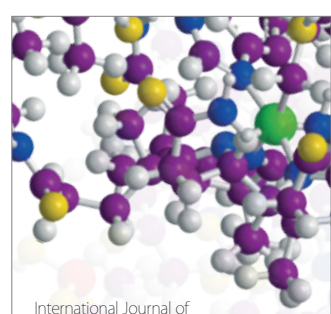

Carbohydrate Chemistry

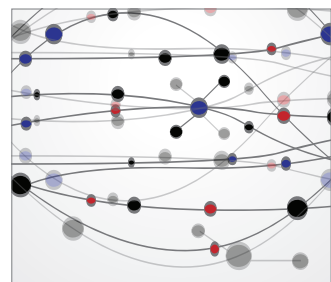

The Scientific World Journal
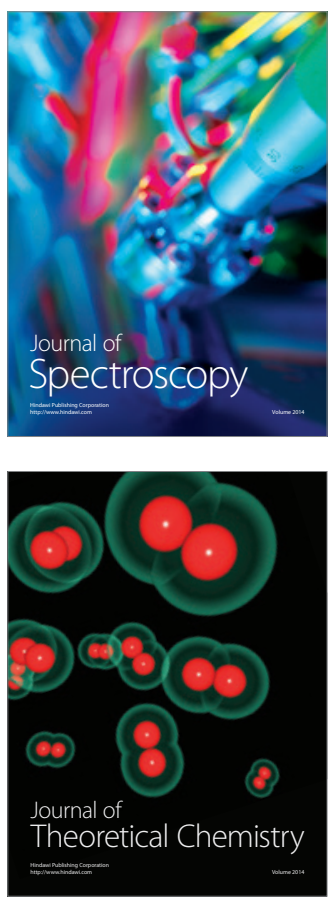
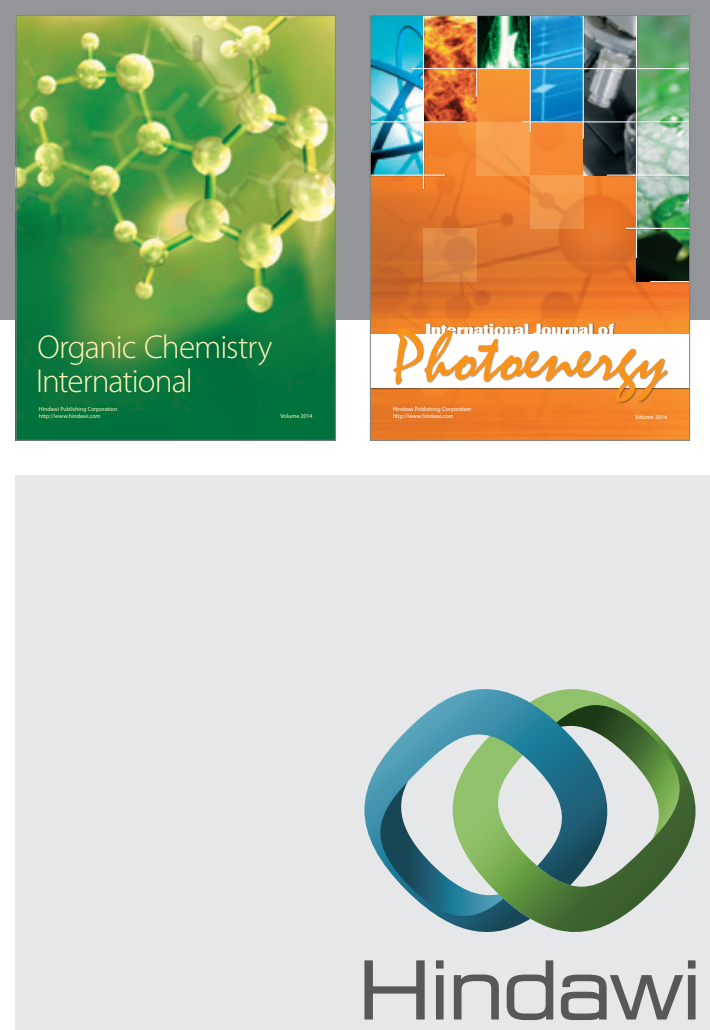

Submit your manuscripts at

http://www.hindawi.com
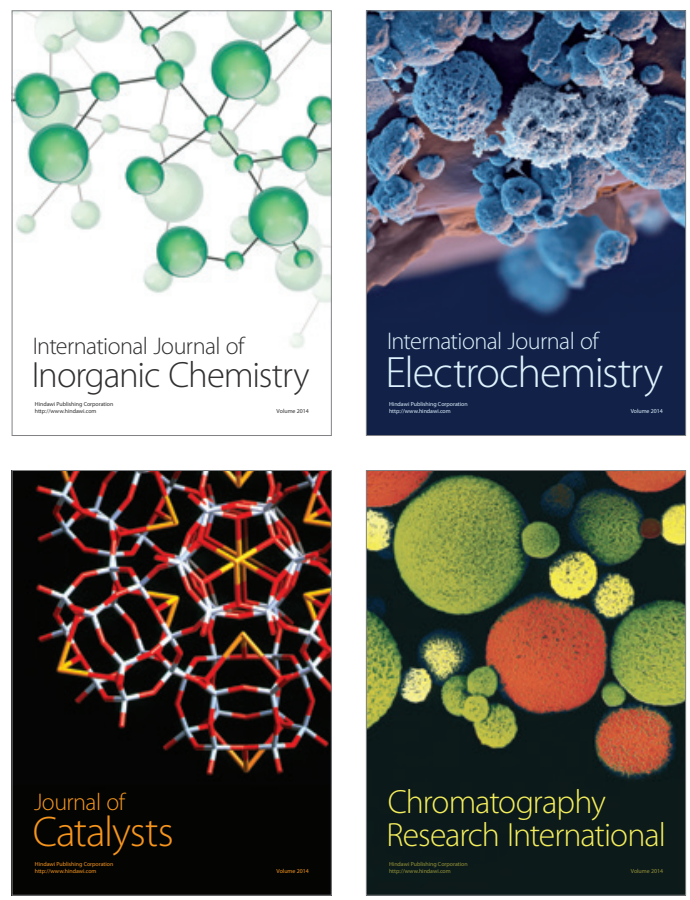
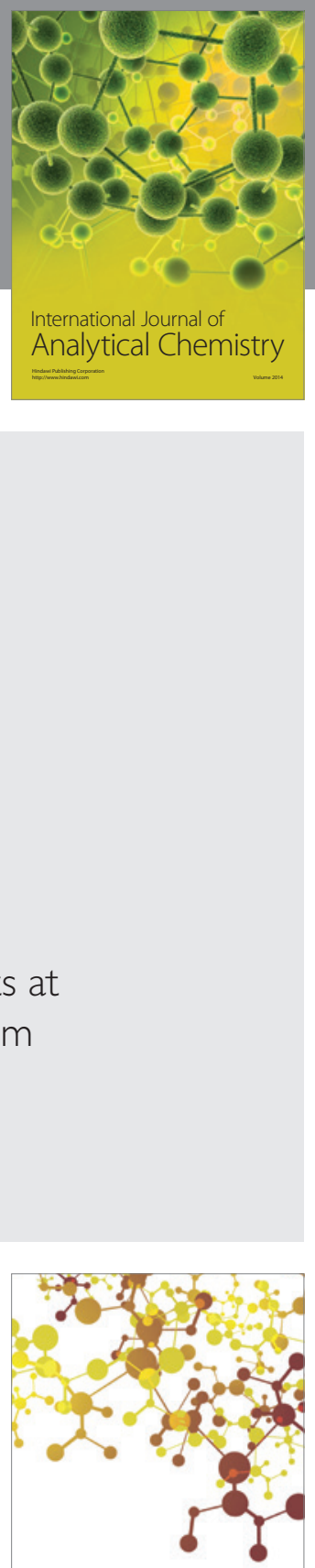

Journal of

Applied Chemistry
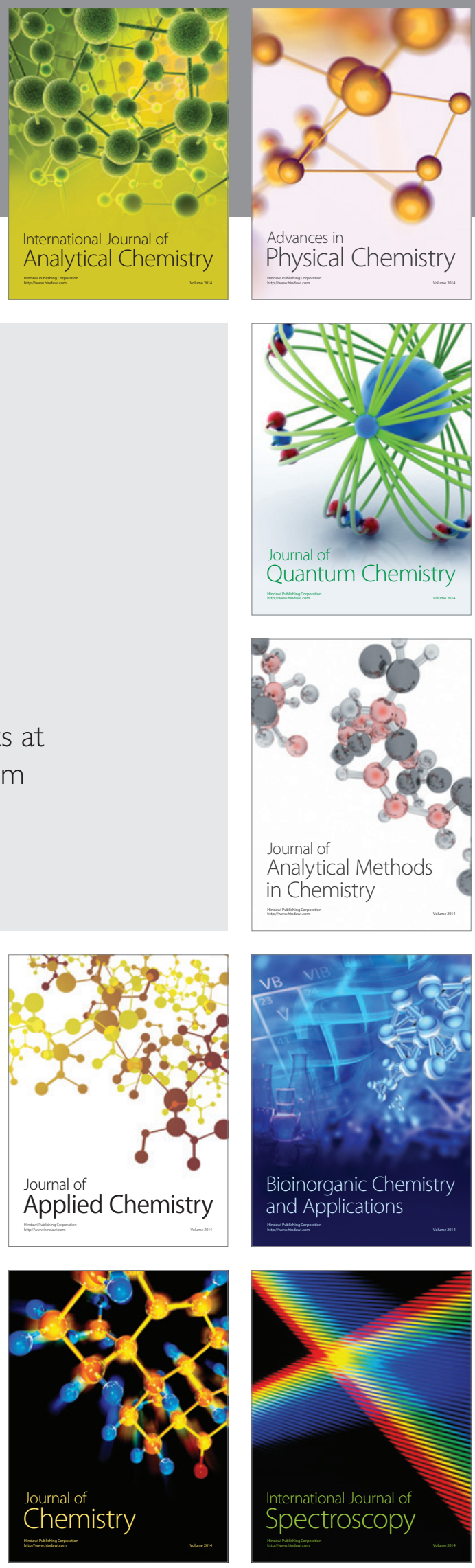